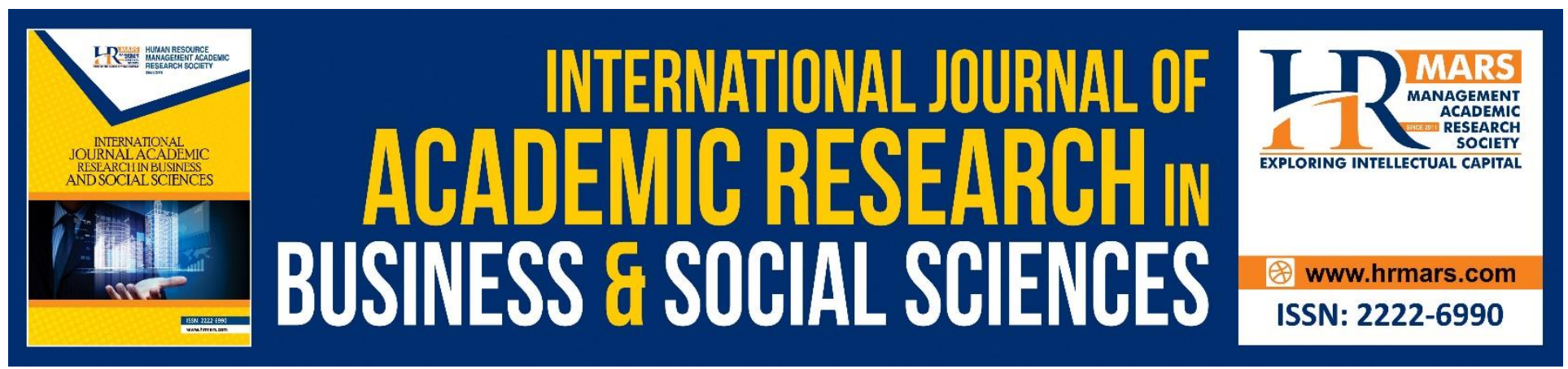

\title{
Accounting Information and Deferred Taxation: Evidence from Deposit Money Banks in Nigeria
}

\author{
Udeh, Francis N. and Ezejiofor, Raymond A.
}

To Link this Article: http://dx.doi.org/10.6007/IJARBSS/v8-i10/4800

DOI: $10.6007 /$ IJARBSS/v8-i10/4800

Received: 13 Sept 2018, Revised: 21 Oct 2018, Accepted: 28 Oct 2018

Published Online: 31 October 2018

In-Text Citation: (Udeh \& Ezejiofor, 2018)

To Cite this Article: Udeh, F. N., \& Ezejiofor, R. A. (2018). Accounting Information and Deferred Taxation:

Evidence from Deposit Money Banks in Nigeria. International Journal of Academic Research in Business and Social Sciences, 8(10), 1052-1069.

\section{Copyright: (C) 2018 The Author(s)}

Published by Human Resource Management Academic Research Society (www.hrmars.com)

This article is published under the Creative Commons Attribution (CC BY 4.0) license. Anyone may reproduce, distribute, translate and create derivative works of this article (for both commercial and non-commercial purposes), subject to full attribution to the original publication and authors. The full terms of this license may be seen

at: http://creativecommons.org/licences/by/4.0/legalcode

Vol. 8, No. 10, 2018, Pg. 1052 - 1069

http://hrmars.com/index.php/pages/detail/IJARBSS

JOURNAL HOMEPAGE

Full Terms \& Conditions of access and use can be found at http://hrmars.com/index.php/pages/detail/publication-ethics 


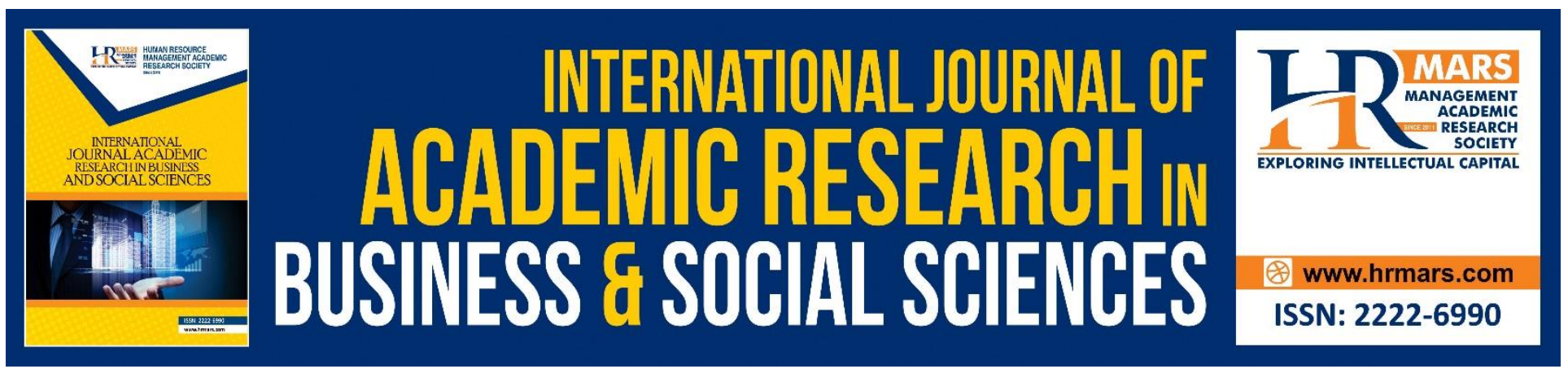

\title{
Accounting Information and Deferred Taxation: Evidence from Deposit Money Banks in Nigeria
}

\author{
Udeh, Francis N. (Ph.D.) and Ezejiofor, Raymond A. (Ph.D.) \\ Department of accountancy Nnamdi Azikiwe University, Awka \\ Email: fn.udeh@unizik.edu.ng \& thaddray4life@yahoo.com
}

\begin{abstract}
This study assesses the effect of accounting information on deferred taxation in Nigerian deposit money banks. The specific objectives are to; evaluate whether earnings per share has effect on deferred tax items of Nigerian deposit money banks and established how cash flow affected deferred tax items of Nigerian deposit money banks. Ex post Facto research design was adopted and the data were collected from annual reports and accounts of Nigerian deposit money banks. Pooled multiple regression analysis was employed to test the formulated hypotheses. Based on the analysis, the study found that earnings per share (EPS) and Cash flow (CASHFL) impact negatively on our dependent variable, deferred tax, but book value of equity impact was statistically significant while earnings per share (EPS) and Cash flow (CASHFL) impact were not statistically significant. The study therefore recommends among others that Since the basis of effectiveness of generating earnings (EPS) to retire deferred tax of the banks does not perform better as the analysis revealed should be should be ignored as a determinant of deferred tax in Nigeria.
\end{abstract}

Keywords: Accounting Information, Deferred Taxation and Nigerian Deposit Money Banks

\section{Introduction}

Deferred taxes are a construct of financial reporting. The purpose of deferred tax accounting is to account for future tax effects that will arise due to different recognition and measurement principles of accounting standards versus tax law. Thus, deferred taxes represent future tax consequences of items and business transactions that have been recognized differently in the financial statement than in the tax report. Specifically, deferred taxes reflect the taxes that would be payable or receivable if the entity's assets and liabilities were recovered / settled at their present carrying amount (Astrid, 2011).

Regarding the special case of deferred tax accounting, it is common knowledge that accounting for deferred taxes is relatively effort- and time-consuming and, hence, relatively costly. COM (2007) stated that "accounting for deferred taxes is very burdensome for companies in general". The high 
accounting costs arise due to the fact that accounting for deferred taxes is rather complex and requires a high level of coordination.

Deferred tax liabilities (DTLs) and deferred tax assets (DTAs) are the important considerations. The true benefits of DTLs tend not to be understood. There are two separate reporting systems: the financial reporting system and the tax reporting system. In the financial reporting system, managers have significant discretion over reported numbers. Due to the flexibility in tax system, thus, investors may prefer to review tax numbers that are free from earnings management (Kelvin, 2010). Unfortunately, only the financial reporting numbers are publicly disclosed. However, investors can utilize the financially reported deferred tax items to reconcile the two systems. In fact, they enable investors to translate the financial results into numbers less subject to discretion and therein produce higher quality information to predict what US stock prices should be.

In detail, the dissertation investigates in three separate empirical studies the cash flow relevance (materiality and predictive value) of disclosed deferred taxes and the impact of deferred taxes on firm value.

Astrid (2011) asserted that since firm value equals the present value of expected firm cash flows, quantification of deferred tax cash flow is particularly important in order to determine the relevance of deferred taxes for firm value and, thus, to determine the decision relevance and usefulness of provided deferred tax information for financial statement users. This is the first study, however, that systematically tries to quantify deferred tax cash flow and that empirically investigates the economic significance of this deferred tax cash flow. Furthermore, this is the first study analyzing the information content of disclosed deferred taxes with respect to future tax cash flow. Since the primary purpose of deferred tax accounting is to inform about future tax benefits and future tax liabilities, an analysis of the relation of currently disclosed deferred taxes to actual future tax cash flow is crucial for assessing whether deferred tax accounting actually meets its intended purpose.

Most of studies concerning this issue and majority of them were carried out in the USA listed on the US Stock Exchange (Chi, Pincus, Teoh, et al, 2014). Petr and Hana (2017) however, indicate that accounting reporting has influence on deferred tax according to IFRS. Ifada and Wulandari (2015) found that deferred taxes significantly affect earnings management. Eberhartinger, Genest and Lee (2014) do not support the notion that such deferred tax information has an effect on the judgment of experts. Most of the previous studies were conducted in foreign countries; the similar studies that carried out in Nigerian deposit money banks in assessing the influence of accounting information on deferred taxation is limited. This study attempts to fill this gap by examining the impact of accounting information on deferred taxation on quoted Nigerian deposit money banks.

This study assesses the effect of accounting information on deferred taxation in Nigerian deposit money banks. Specifically, the study intend to:

1. To evaluate whether earnings per share has effect on deferred tax items of Nigerian deposit money banks.

2. To established how cash flow affected deferred tax items of Nigerian deposit money banks. 


\section{REVIEW OF RELATED LITERATURE Conceptual Framework

Deferred tax accounting is an outcome of the matching principle, aiming at recognizing the tax consequences of an item reported within the financial statements in the same accounting period as the item itself. Thereby, total tax expense reflects the tax expenses / tax benefits that are attributable to pre-tax book income but that are not reflected in current tax expense of the period (Astrid, 2011). In a period of higher payable income tax, the company increases the reported profit by creation of deferred tax asset or by use of deferred tax liability. Astrid (2011) stated that the overall usefulness of deferred tax accounting is on debate continuously. Critics argue that the informative value of deferred taxes is only low due to highly uncertain cash flow implications, which results in most financial statement users ignoring deferred tax disclosures, since these are not considered to provide relevant information for decision making.

Dhaliwal, Trezevant and Wilkins (2000) determine whether deferred tax liabilities (DTLs) that are not reported on the financial position are valued in the context of FIFO or LIFO choices. If investors choose to value all companies based on FIFO, it would require an adjustment of LIFO to this method. If the general market has increasing costs for inventory, then some price effect could result from implying an increase to DTLs. Dhaliwal et al. (2000) find that the market does value the DTLs that are not on the balance sheet.

According to Noga and Schnader (2013), there is one more reason for reporting of the differences between firm's book income and its taxable income. It is a questionable reason. The questionable reasons are based on an intentional manipulation with financial statements, tax evasion, etc. However in the situation the most effective firm management is expected to take advantage of legal tax planning techniques, the unusually large differences between book and taxable income can potentially indicate the company uses illegal options for decrease its tax base or increase a profit for external users of financial statements.

\section{Deferred Tax Assets}

Deferred tax asset is an accounting term that refers to a situation where a business has overpaid taxes or taxes paid in advance on its balance sheet. These taxes are eventually returned to the business in the form of tax relief, and the over-payment is, therefore, an asset for the company. A deferred tax asset can conceptually be compared to rent paid in advance or refundable insurance premiums; while the business no longer has cash on hand, it does have comparable value, and this must be reflected in its financial statements.

Deferred tax assets generally arise where tax relief is provided after an expense is deducted for accounting purposes:

i. a company may accrue an accounting expense in relation to a provision such as bad debts, but tax relief may not be obtained until the provision is utilized

ii. a company may incur tax losses and be able to "carry forward" losses to reduce taxable income in future years.. 
INTERNATIONAL JOURNAL OF ACADEMIC RESEARCH IN BUSINESS AND SOCIAL SCIENCES Vol. 8, No. 10, Oct. 2018, E-ISSN: 2222-6990 @ 2018 HRMARS

\section{Net Deferred Tax Liability}

Deferred tax liabilities are financially recorded income that has not yet been taxed, for example in the case of accelerated tax depreciation, in this case, taxable income is deferred into the future by tax depreciation rates that exceed book depreciation rates. Yulianti (2005) as well as Wijaya and Martani (2011) stated that deferred tax liability increase when a company accelerates the earnings recognition or defers the debt recognition (accelerate the debt or defer the earnings) for accounting purposes as compared to corporate tax purposes. With such pattern, the company will report higher accounting earnings compared to earnings from the tax. As a result, it will increase net deferred tax liability of the company, and vice versa (Wijaya and Martani, 2011).

\section{Deferred Tax Assets and Liabilities (Recognition and Measurement)}

IFRS/IAS and US GAAP follow the liability method of deferred tax accounting. Thereby, deferred tax liabilities (deferred tax assets) account for the amounts of income taxes payable (recoverable) in future periods that arise from temporary book-tax differences, i.e., differences between the book value of an asset or a liability and its tax base that will result in taxable (tax deductible) amounts when the book value of the asset / liability is recovered / settled.

Recognition of and changes in deferred taxes generally affect book income through deferred tax expense. Yet, (changes in) deferred taxes are recognized directly in equity, i.e., are income neutral, if the underlying transaction or event, which causes the book-tax difference, is recognized outside profit or loss (IAS 12.58).

Deferred tax liabilities arise generally from financially recorded income that has not yet been taxed, for example in the case of accelerated tax depreciation, where taxable income is deferred into the future (as compared to book income) by tax depreciation rates that exceed book depreciation rates. Conversely, deferred tax assets arise generally as a result of earlier expensing for financial accounting than for tax purposes. Thereby, deferred tax components can reflect book-tax differences that arise automatically due to differences in tax law versus accounting principles, as well as book-tax differences that inform about choices made for book purposes.

Deferred tax assets arising from book-tax differences in pension provisions, for example, imply that firms usually use a lower discount rate in the calculation of the pension provision for book purposes than for tax purposes. For instance, Stadler (2010) reports that the average (median) pension discount rate used in consolidated financial statements of German firms is 5.24 (5.50) percent, whereas German tax law requires a fixed discount rate of 6 percent (6a (3).

In contrast, temporary book-tax differences in provisions reflect fixed differences in tax law versus accounting principles, since provisions are recognized under IFRS/IAS (IAS 37.10) for liabilities of uncertain timing or amount, whereas these liabilities are generally not relevant for tax purposes until payable amounts are actually fixed (Astrid, 2011). Book-tax differences in current assets, as another example, may give rise to either deferred tax assets or deferred tax liabilities (for example, inventory may be written down for book purposes but not for tax purposes, resulting in a deferred tax asset; valuation of inventory according to FIFO for book purposes versus average value for tax purposes may give rise to either a deferred tax asset or a deferred tax liability).

These show that main parts of deferred taxes are generally due to recurring operating activities. Beside deductible temporary differences, deferred tax assets also have to be recognized for unused 
tax loss carry forwards and unused tax credit carry forwards (IAS 12.34). Thereby, deferred tax assets are only allowed to be recognized to the extent that the realization of the related tax benefits is "probable", i.e., to the extent that it is probable that taxable profit will be available against which the deductible temporary difference, the unused tax losses and tax credits can be utilized (IAS $12.24 \&$ IAS 12.34).

Using deferred tax assets (DTA's) to predict stock prices has not received attention in the literature, perhaps because the number of researchers who have the necessary understanding of financial and tax accounting is not extensive. Together the meaning of DTLs and DTAs under FAS 109 requires knowledge of financial and tax accounting (Graham et al., 2010). Financial accounting implies that liabilities are not preferred, so many consider DTAs are superior to DTLs in their value to companies. Unfortunately, this understanding is not correct.

The underlying factors, which are not directly related to deferred tax cash flow, but which might influence value relevance as correlated omitted variables through recognition decisions in the context of deferred tax asset recognition, are shown below:

(a) Except for large net deferred tax assets, deferred taxes are generally not reflected in firm value, i.e., investors do in general not expect deferred taxes to result in material cash flow in the near future.

(b) There is some reversal in the balances in the short-run. The magnitude of these reversals, however, is rather small, suggesting that large implied deferred tax cash flows are rare.

(c) Reversal as well as regression analyses suggest that deferred taxes have indeed timely cash flow implications. Yet, the economic significance of implied deferred tax cash flow seems to be rather small. Estimations of deferred tax cash flow based on regression analyses suggest that deferred tax cash flow constitutes less than 5 percent of total tax cash flow for the majority of observations.

(d) The analysis of the long-term development of deferred tax balances clearly shows that deferred tax balances continuously increase in the long-run.

(e) Deferred taxes are not (materially) informative about future tax cash flow for the majority of observations.

\section{The Value Relevance of Deferred Taxes}

There are two opposed theories with respect to the value relevance of deferred taxes: liability view versus equity view. While proponents of the liability view argue that deferred tax liabilities (deferred tax assets) account for future tax liabilities (future tax benefits) and should therefore contribute negatively (positively) to firm value, proponents of the equity view reason that associated cash flows are highly uncertain, with a present value close to zero, and deferred taxes should therefore be of no value relevance (Astrid, 2011).

According to IAS 12.5, deferred tax liabilities (deferred tax assets) account for the amounts of income taxes payable (recoverable) in future periods that arise from temporary book-tax differences, i.e., differences between the book value of an asset or a liability and its tax base that will result in taxable (tax deductible) amounts when the book value of the liability (asset) is settled (recovered). Deferred tax liabilities arise, for example, from accelerated tax depreciation or from financially recorded income that has not yet been taxed. Deferred tax assets are recognized for the probably realizable tax benefits of tax loss carry forwards and arise, for example, from provisions for warranty costs or 
bad debts, which are already expensed for book purposes, but which are not tax deductible until the provision is utilized. the firm will most likely be in severe financial difficulties, with the consequence that accruing tax benefits (tax liabilities) cannot be used (paid) because of lacking taxable income (cash inflow), such that deferred tax cash flow will not be realized even in case of reversing temporary differences. For these reasons, proponents of the equity view argue that deferred taxes account principally for distant and - in several dimensions - uncertain cash flows, being of no or only little relevance for the amount of tax payments in the next years, the associated cash flows having a present value that is close to zero. Therefore, deferred taxes are effectively part of equity according to this view.

Empirical evidence on whether financial statement users take deferred tax information into account is rather inconclusive. Using similar data, Amir and Kirschenheiter (1997) and Ayers (1998) provide evidence consistent with the liability view and the market discounting deferred tax components according to their expected time and likelihood of reversal, while Chang, Herbohn and Tutticci, (2009), using Australian data, find only deferred tax assets to be value relevant. By contrast, Chandra and Ro (1997) provide evidence consistent with the equity view by showing that deferred taxes and stock risk are related negatively. Chen and Schoderbek (2000) report that deferred tax adjustments as a consequence of a change in the corporate tax rate were reflected in share prices at the same rate as recurring earnings, despite their different implications for future cash flows. Apparently, investors did not expect the income effects due to tax rate change-induced deferred tax adjustments, which suggests either that investors are not familiar with deferred tax accounting rules, the concept of deferred taxes, or that they ignore deferred taxes altogether. Consistent with the latter, Lev and Nissim (2004) find no significant relation between deferred tax expense and annual returns, which suggests that investors do not consider deferred taxes to be relevant.

\section{Accounting Information}

According to Meyer (2007), "accounting plays a significant role within the concept of generating and communicating wealth of companies". Accounting data, such as earnings per share, is termed value relevant if it is significantly related to the dependent variable, which may be expressed by price, return or abnormal return (Gjerde, Knivsfla \& Saettem, 2007).

Accounting information is any data or information obtained from the accounting system of a firm whether contained in a financial statement, a special report, or verbal statement (William, 1968). Sibel, (2013) opine that accounting information contained in financial statements is expected to be useful for decision makers. In order to provide this, financial statements should meet some basic characteristics. "If financial information is to be useful, it must be relevant and faithfully represent what it purports to represent. The usefulness of financial information is enhanced if it is comparable, verifiable, timely and understandable" (CFFR, 2010).

\section{Earnings Per Share}

Earnings per share considered as the most frequently used accounting information in value relevance studies. By using the formula given by them earnings per share calculated by taking earnings after tax, interest and depreciation divided by the total number of outstanding shares. 
Moreover, Earning is a fundamental and prominent accounting variable when it comes to the investigation of the value relevance of accounting information. This is due to its superiority over cash flow in this regard. However, the market will look out for both cash flow and net book value if the earnings numbers are perceived to be inadequate (Abiodun, 2012). The earnings per share which is a parameter that can be used to measure the earnings ability of firms is required to be disclosed by companies quoted or about to be quoted in the public security market (Valix \& Peralta, 2009). The non-public enterprises to the extent that it would enhance their financial report comparability, are encouraged to present their EPS on the face of their income statements (Menaje, 2012). Contrary to the past practices of presenting information on the earnings per share in the form of primary and fully diluted EPS, the Financial Accounting Standard Board (FASB) now requires the discloses of both the basic and fully diluted EPS (FASB, 1997). This new practice of EPS disclosure is being motivated by the need to confirm the calculation of EPS to the international standard and to assist the investors to better access the effect of potential dilution than that achieved under the primary EPS (Livant \& Segal, 2000).

Most of the studies done on examine value relevance of earnings per share on share price, results reported to be significant and positive related with share price, this supported by the results found by Pathirawasam, (2010) in Sri-Lanka observed earnings per share to have positive value relevance on the market share price of 129 companies selected from 6 major sectors listed at Colombo stock exchange and other study done by different researchers including Tharmila and Nimalathasan (2013) and Vijitha, and Namalathan (2014) in Sri-Lanka, by Ragab and Omiran (2006) in Egyptian market. Earnings per share were sourced from profit and loss statement of the company by dividing the profit after tax by the number of outstanding shares for the respective period.

\section{Empirical Review}

Using data gathered from firms' income tax footnote disclosures, Phillips, Pincus, Rego, and Wan (2004) investigate the relationship between earnings changes and corresponding changes in the deferred tax account. They found evidence that the changes in the deferred tax account related to expense accruals and reserves can be used to detect earnings management both to avoid an earnings decline, as well as to report earnings increases.

Noor, Mastuki, and Aziz (2007) use data from the Bursa Malaysia (Malaysian stock exchange) in a replication of Phillips, Pincus and Rego (2003) to investigate whether firms use deferred tax expense to manage earnings in order to (1) avoid an earnings decline, and (2) to avoid a loss. They found evidence that firms use deferred tax expense and discretionary accruals to avoid a loss. However, they were not able to support their hypothesis that deferred tax expense and discretionary accruals were used to avoid an earnings decline.

In a somewhat novel approach, Ifada and Wulandari (2015) examine the use of deferred tax expense to manage taxable income (and corresponding tax payments), rather than financial accounting income. While they found that deferred taxes significantly affect earnings management, they found no support for company size or tax planning activities affecting earnings management.

In a study of 58 British firms, Holland and Jackson (2004) found significant use of under- or overprovisions of deferred tax, and that such provisions accounted for approximately $9 \%$ of before tax profit or loss. They examined the deferred tax provisions in the context of three variables, and found 
that the level of under- or over-provisions positively related to (1) whether a pre-tax profit or loss is reported, (2) any adjustment of a prior year tax amount, and (3) the level of surplus advance corporation tax. They found strong evidence supporting the use of deferred tax characteristics in the smoothing of income.

Eberhartinger, Genest and Lee (2014) investigate the relevance of specific tax accounting information in an experimental setting. Participants make judgments on the financial performance, investment attractiveness and tax position of the firm, in absence or in presence of detailed tax information in the other comprehensive income statement. Their results do not support the notion that such deferred tax information has an effect on the judgment of experts, as long as the amounts of deferred tax are normal. However, when the detailed amounts of deferred tax are abnormally high, judgment differs significantly. Their result is important for standard setters, as they may consider further developing guidance in standards (such as IAS 1 and IAS 12) and in the Practice Statement for how to judge materiality of information, in accordance with the materiality principle set forth in IAS 1.31. Their results are novel and the method used allows for the isolation of effects and the identification of causal relationships.

Ying, Scott and Micheal (2016) study uses data collected from CSMAR, the China Center for Economic Research, for the period 2009-2015. The study develop a more practical method of measuring earnings management using deferred tax items and compare the new method to the traditional approach. The study find that the new method is effective and may be used alone on individual companies or as a complement to other earnings measurement techniques, since the new method focuses on different data.

Phillips, Pincus and Rego (2003) hypothesize that a greater level of discretion in calculating financial accounting income (according to GAAP) when compared to the calculation of taxable income (according to the Internal Revenue Code) will allow managers to utilize that discretion to manage income in a positive manner, but in ways that do not also increase taxable income. This type of discretionary earnings management will create timing differences that result in an increase in deferred tax expense. They found that earnings management resulting from both total accruals and abnormal accruals was successfully utilized to avoid both an earnings decline as well as a loss, but only total accruals were successfully used to detect earnings management to meet analyst forecasts. Schrand and Wong (2003) attempted to determine if banks used high valuation allowances for deferred tax assets to manage future earnings. They found that banks created "hidden reserves" with high valuation allowances associated with deferred tax assets, and those reserves were used to manage earnings toward the consensus analyst forecast.

Bauman, Bauman and Halsey (2001) sampled Fortune 500 firms in order to examine whether earnings management was affected by changes in the deferred tax asset valuation allowance account. Contrary to the results obtained by others, they found that it is often impossible to determine the earnings effect of a valuation change from the financial statement disclosures. In addition, they found evidence that amounts used in the effective tax rate reconciliation are a better measure of earnings management, compared to using changes in the valuation account.

Petr and Hana (2017) paper is concerned with the influence of a financial reporting system on a deferred tax reporting. The continental and Anglo-Saxon reporting systems are compared. The materiality of the deferred tax item is used as a means for evaluation of the impact of deferred tax 
reporting. The category of deferred income tax is assessed on a sample of companies operating in the chemical industry (NACE 20.1) and reporting in accordance with the Czech accounting legislation (representative of continental reporting system) in the time series from 2005 to 2015 . The results are compared with the results of author's previous study concerning the reporting of deferred tax according to IFRS (representative of Anglo-Saxon reporting system).

Blaylock, Shevlin and Wilson (2012) examined book-tax differences as a signal of earnings persistence. They find that there are multiple potential sources of book-tax differences. Then they examined the differing implications of large positive book-tax differences for earnings and accruals persistence depending on the source of those book-tax differences. They illustrated the importance of the source of the book-tax differences.

Kevin (2010) examines whether deferred tax ratios predict US stock prices. Correlation and regression establish the ratio of deferred tax liabilities over shares is more related to price than traditional ratios, such as basic earnings per share, earnings per share including extra items, cash flow per share, and book value per share. Hanlon (2005) review whether estimated taxable income discloses certain information relevant to price that book income does not. Their results show that book income has the larger coefficient and t-statistic. However, estimated taxable income still is statistically significant, which indicates that it provides information that book income does not. Nevertheless, they do discover that overall book income is more value relevant than taxable income.

Thomas and Zhang (2007) look at the relationship between estimated taxable income and future returns. Unexpected results for estimated taxable income correspond with stock returns six months later. Lev and Nissim (2004) find it to be one year. Thomas and Zhang (2007) discuss two reasons for this discovered relationship. The tax surprise could forecast subsequent book income not ascertainable from the current book income numbers. It could also forecast other subsequent financial information.

Weber (2009) show that only for companies with lower-quality information does the relationship between book-to-tax differences and future returns exist. The research finds that prediction errors are statistically significant to taxable-to-book-income ratios. It also discloses that prediction errors are more positive where large book-to-tax differences exist. Chen et al. (2003) support these results.

Graham, Raedy and Shackelford (2010) demonstrate that tax information has an effect on future stock returns and prices. As this literature review has shown, there is incremental value to DTLs. There are also two lines of research into DTLs. Despite all this deferred tax research, there has not been inquiry into whether deferred tax ratios can predict stock prices.

Chi, Pincus and Teoh (2013) found evidence that investors misprice information contained in BTDs, measured as ratio of taxable income to book income. Philips et al., 2003; Hanlon, 2005; Blaylock, 2012) assessed if the usefulness of deferred tax expense in detecting earnings management.

Meanwhile, Petr and Hana (2017) show that accounting reporting has influence on deferred tax according to IFRS. Ifada and Wulandari (2015) found that deferred taxes significantly affect earnings management. Eberhartinger, Genest and Lee (2014) do not support the notion that such deferred tax 
information has an effect on the judgment of experts. Kevin (2010) established that deferred tax liabilities over shares is more related to price than traditional ratios, such as basic earnings per share, earnings per share including extra items, cash flow per share, and book value per share. Most of the previous studies were conducted in foreign countries; and the similar studies that carried out Nigerian deposit money banks in assessing the influence of accounting information on deferred taxation are limited. This study attempts to fill this gap by examining the impact of accounting information on over deferred taxation on quoted Nigerian deposit money banks.

\section{RESEARCH METHODOLOGY}

\section{Research Design}

Due to the nature of the study, ex-post facto research design was adopted. This is appropriate because the study aims at measuring the relationship between one variable and another in which the variables are not manipulated. This involves use of financial accounts of organizations to generate the financial analysis that will determine the significant difference.

\section{Population of the Study}

The population of the study consists of fifteen (15) quoted money deposit banks on the Nigerian stock exchange. They includes; Access bank plc; Diamond bank plc; First bank plc; Skye bank plc; FCMB plc; GTB plc; Zenith bank plc; Sterling bank plc; UBA plc; Fidelity bank plc; Stanbic IBTC; Union bank plc; Unity Bank Plc; Wema bank plc and Eco bank Plc.

\section{Method of Data Analysis}

To achieve the objectives of this study, the data required were those of the discriminating variables that include: debt level, net deferred tax, interest expenses and firm size of deposit money banks quoted on Nigerian Stock Exchange from 2010 to 2016. Hypotheses formulated for the study were tested with the pooled multiple regression using Statistical Package for Social Sciences (SPSS) version 20.0 software package.

\section{Decision rule:}

Using SPSS, $5 \%$ is considered a normal significance level. The accept reject criterion was based on the p-value, alternative hypothesis will be accepted.

The researcher modified Ying, Scott and Micheal (2016) modern of deferred tax items and earning management as follows:

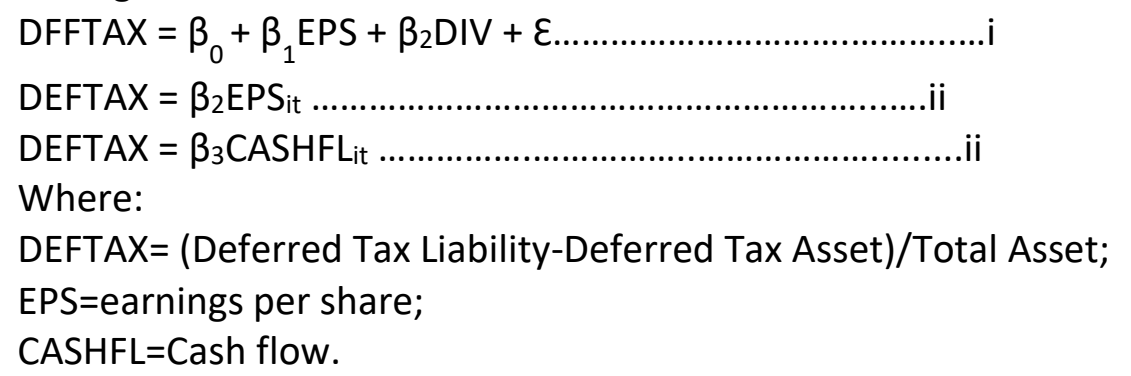




\section{DATA PRESENTATION AND ANALYSIS \\ Data Analysis \\ Table 1: Correlation Analysis Matrix \\ DEFRD EPS CASHFL \\ $\begin{array}{llll}\text { DEFRD } & 1.00 \quad 0.08 & 0.33\end{array}$

$\begin{array}{llll}\text { EPS } & 0.08 & 1.00 & 0.06\end{array}$ \\ \begin{tabular}{llll} 
CASHFL & 0.33 & 0.06 & 1.00 \\
\hline
\end{tabular}}

Source: researcher's computation (2018)

The use of correlation matrix in most regression analysis is to check for multi-colinearity and to explore the association between each explanatory variable (EPS and CASHFL) and the dependent variable (DEFRD) proxy as deferred tax assets and liability. Table 1 focused on the correlation between deferred tax measured as deferred tax assets less deferred tax liability over total asset and the independent variables (EPS and CASHFL).

Finding from the correlation matrix table shows that all our independent variables, (EPS $=0.08$ and CASHFL=0.33) were observed to be positively and weakly associated with deferred tax. In checking for multi-colinearity, we notice that no two explanatory variables were perfectly correlated. This means that there is no problem of multi-colinearity between the explanatory variables. Multicolinearity may result to wrong signs or implausible magnitudes in the estimated model coefficients, and the bias of the standard errors of the coefficients.

\section{Testing of Hypotheses formulated}

In other to examine the impact relationships between the dependent variable DEFRD and the independent variables (BVE, BMP, EPS and CASHFL) and to also test our formulated hypotheses, we used a pooled multiple regression analysis since the data had both time series (2010-2016) and cross sectional properties (15 deposit money banks). The pooled interaction based multiple regression results are presented and discussed in Table 3 below

Table 2: DEFRD Pooled Regression Results

Dependent Variable: DEFRD

Method: Panel Least Squares

Date: 04/02/18 Time: 23:10

Sample: 20102015

Periods included: 6

Cross-sections included: 15 
INTERNATIONAL JOURNAL OF ACADEMIC RESEARCH IN BUSINESS AND SOCIAL SCIENCES Vol. 8, No. 10, Oct. 2018, E-ISSN: 2222-6990 @ 2018 HRMARS

Total panel (balanced) observations: 90

\begin{tabular}{lrrrr}
\hline \hline \multicolumn{1}{c}{ Variable } & Coefficient & Std. Error & t-Statistic & Prob. \\
\hline \hline \multicolumn{1}{c}{ C } & 0.047628 & 0.007002 & 6.802146 & 0.0000 \\
EPS & -0.000236 & 0.000443 & -0.532844 & 0.5955 \\
CASHFL & $-3.48 \mathrm{E}-11$ & $1.80 \mathrm{E}-11$ & -1.928040 & 0.0572 \\
\hline \hline R-squared & 0.196822 & Mean dependent var & 0.021489 \\
Adjusted R-squared & 0.159025 & S.D. dependent var & 0.033200 \\
S.E. of regression & 0.030446 & Akaike info criterion & -4.091763 \\
Sum squared resid & 0.078792 & Schwarz criterion & -3.952885 \\
Log likelihood & 189.1293 & Hannan-Quinn criter. & -4.035759 \\
F-statistic & 5.207393 & Durbin-Watson stat & 0.501687 \\
Prob(F-statistic) & 0.000843 & & \\
\hline \hline
\end{tabular}

In Table 2, R-squared and adjusted Squared values were (0.20) and (0.16) respectively. The indicates that all the independent variables jointly explain about $20 \%$ of the systematic variations in deferred tax (DEFRD) of our samples banks over the seven years periods (2010-2016). The F-statistics (5.21) and its $P$-value $(0.00)$ show that the DEFRD regression model is well specified.

Test of Autocorrelation: using Durbin-Waston (DW) statistics which we obtained from our regression result in table 4.3, it is observed that DW statistics is 0.50 and an Akika Info Criterion and Schwarz Criterion which are -4.09 and -3.95 respectively also further confirms that our model is well specified. In addition to the above, the specific findings from each explanatory variable are provided as follows: Earnings Per Share (EPS), based on the t-value of -0.532844 and $p$-value of 0.5955 was found to have a negative influence on our sampled quoted banks deferred tax and this influence is statistically significant at $10 \%$ level since its $p$-value is more than 0.10 value. This result therefore suggests that we should reject our null hypothesis three $\left(\mathrm{HO}_{3}\right)$ which states that earnings per share have no significant effect on deferred tax item of deposit money banks in Nigeria. This means that for every \#1 increase in cash of firms will lead to about \#0.5 decrease in deferred tax, although this influence is not statistically significant and it cannot be used for any policy formulation.

Cash Flow (CASFLW), based on the t-value of -1.928040 and p-value of 0.0572 , was found to have a negative influence on our sampled quoted banks deferred tax and this influence is not statistically significant since its $p$-value is less than $0.10 \%$. This result, therefore suggests that we should accept our null hypothesis four $\left(\mathrm{Ho}_{4}\right)$ which states that the cash flow has no significant effect on deferred tax item of deposit money banks in Nigeria. This means that for every \#1 increase in cash of firms will lead to about \#0.5 decrease in deferred tax, although this influence is statistically significant and it can be used for any policy formulation.

Discussion of Result 
Earnings per share (EPS) based on findings, were found to impact negatively on our dependent variable, deferred tax. This impact was not statistically significant. This finding therefore supports our aprori expectation and the findings of Noor, Mastuki, and Aziz (2007) and negates the view of Phillips, Pincus, Rego, and Wan (2004).

Cash flow (CASHFL) based on findings, was found to impact negatively on our dependent variable, deferred tax. This impact was statistically significant. This finding therefore supports our aprori expectation and the findings of Schrand and Wong (2003) and negates the view of Ifada and Wulandari (2015).

\section{Conclusion}

The category of deferred tax is a specific issue that interconnects the area of accounting information, because the category of deferred income tax is significant the assumption should be that the behavior and the incentives will be affected by the deferred income tax in both accounting systems. There has been little rigorous empirical analysis of the deferred tax and accounting information. In this study, we attempt to fill this void, at least in part, by investigating the significant effect of accounting information on deferred tax. The study also found that earnings per share (EPS) impact negatively on our dependent variable, deferred tax, but this impact was not statistically significant, and Cash flow (CASHFL) was found to impact negatively on our dependent variable, deferred tax, but this impact was statistically significant. Conclusively, Correlation and regression establish that deferred tax is more related to book value of equity and cash flow than traditional ratios, such as basic earnings per share, and market price per share.

\section{Recommendations}

Based on the findings of the study, the researcher recommends the followings:

1. Since the basis of effectiveness of generating earnings (EPS) to retire deferred tax of the banks does not perform better as the analysis revealed should be should be ignored as a determinant of deferred tax in Nigeria.

2. The basis of effectiveness of generating cash to determine deferred tax of the banks, it should be used for any policy formulation.

\section{References}

Abiodun, B. Y. (2012). Significance of accounting information on corporate values of firms in Nigeria. Research journal in organizational psychology \& educational studies 1(2) 105-113, pp. 105 113.

Amir, E., \& Kirschenheiter, M. (1997). The valuation of deferred taxes. Contemporary Accounting Research, 14, 597-622.

Ayers, B. (1998). Deferred tax accounting under SFAS No. 109: an empirical investigation of its incremental value-relevance relative to APB No. 11. The Accounting Review, 73, 195-212. 
INTERNATIONAL JOURNAL OF ACADEMIC RESEARCH IN BUSINESS AND SOCIAL SCIENCES

Vol. 8, No. 10, Oct. 2018, E-ISSN: 2222-6990 ㄷ 2018 HRMARS

Astrid, K. C. (2011). The Impact of Deferred Taxes on Firm Value: Three Empirical Studies on the Cash Flow and Value Relevance of Deferred Taxes and Related Disclosures. Inauguraldissertation zur Erlangung des Doktorgrades der Wirtschafts- und Sozialwissenschaftlichen Fakultat der Universitat zu Koln.

Barth, M. E., Beaver, W. H. \& Landsman, W. R.. (1998). Relative Valuation Roles of Equity Book Value and Net Income as a Function of Financial Health. Journal of Accounting and Economics 25: 134.

Bauman, C.C., M.P. Bauman, \& Halsey. R.F. (2001). Do firms use the deferred tax asset valuation allowance to manage earnings? Journal of the American Taxation

Association, 23 (Supplement): 27-48.

Blaylock, B., Shelvin T. \& Wilson, R. J. (2012). Tax Avoidance, Large Positive Temporary Book-Tax Differences, and Earnings Persistence. The Accounting Review, 87(1): $91-120$.

Chang, C., Herbohn, K. \& Tutticci, I. (2009). Market's perception of deferred tax accruals. Accounting and Finance 49 (4): 645-673.

Chandra, U., \& Ro, B.T. (1997). The association between deferred taxes and common stock risk. Journal of Accounting and Public Policy 16 (1): 6-13.

Chen, K.C.W., \& Schoderbek, M.P. (2000). The 1993 Tax Rate Increase and Deferred Tax Adjustments: A Test of Functional Fixation. Journal of Accounting Research 38 (1): 23-44.

Chi, S. S., Pincus, M. \& Teoh, S. H. (2014). Mispricing of Book-Tax Differences and the Trading Behavior of Short Sellers and Insiders. The Accounting Review, 89(2): 511 - 543.

Commission of the European Communities, (2007). Communication from the Commission on a simplified business environment for companies in the areas of company law, accounting and auditing. $\operatorname{COM}(2007) 394$ final. Available at:

http://ec.europa.eu/internal market/company/docs/simplification/com2007 394 en.pdf.

Dhaliwal, D., Trezevant, R., and Wilkins, M. (2000), Tests of deferred tax explanation of the negative association between the LIFO reserve and firm value. Contemporary Accounting Research, 17, 41-59.

Eberhartinger, E. \& Klosterman, M. (2007). What If IFRS Were a Tax Base? New Empirical Evidence from an Austrian Perspective. Accounting in Europe, 4(2): 141 - 168.

Eberhartinger, E., Genest, N. \& Lee, S. (2014). Practitioners' Judgment and Deferred Tax Disclosure: A Case for Materiality. WU International Taxation Research Paper Series. 
INTERNATIONAL JOURNAL OF ACADEMIC RESEARCH IN BUSINESS AND SOCIAL SCIENCES

Vol. 8, No. 10, Oct. 2018, E-ISSN: 2222-6990 ㄷ 2018 HRMARS

Feltham, G. A., and Ohlson, J. A. (1995). Valuation and clean surplus accounting for operating and financial activities. Contemporary Accounting Research 11 (2): 689-731.

Freedman, J. \& Macdonald, G. (2007). The Tax Base for CCCTB: The Role of Principles. Working paper 08/07. Oxford University Centre for Business Taxation.

Graham, J.R., Raedy, J. S. \& Shackelford. D.A. (2011). Research in Accounting for Income Taxes. Working Paper.

Hanlon, M., Hoopes, J. L. \& Shroff, N. (2014). The Effect of Tax Authority Monitoring and Enforcement on Financial Reporting Quality. The Journal of the American Taxation Association, 36(2): 137 - 170.

Ifada, L. M., \& Wulandari, N. (2015). The effect of deferred tax and tax planning toward earnings management practice: an empirical study on nonmanufacturing companies listed in Indonesia stock exchange in the period of 2008-2012. International Journal of Organizational Innovation, 8(1), 155-170

Jackson, M. (2015). Book-Tax Differences and Future Earnings Changes. The Journal of the American Taxation Association, 37(2):49 - 73.

Kevin, A. D. (2010). Ratio of deferred tax liabilities to shares as a predictor of stock prices. Accounting and taxation 2(10.

Laux, R. C. (2013). The Association between Deferred Tax Assets and Liabilities and Future Tax Payments. The Accounting Review, 88(4): 1357 - 1383.

Lev, B., \& Nissim. D. (2004). Taxable income, future earnings, and equity values. The Accounting Review 79 (4): 1039-1074.

Livant, J. \& Segal, D. (2000). The calculation of earnings per share and market value of equity: Should common stock equivalents be included?

Menaje, P. M. (2012). Impact of selected financial variables on share price of publicly listed firms in Philippines. American international journal of contemporary research, 2(9), 98-104.

Marris, R., \& Singh, A. (1966). A measure of a firm's average share price, Journal of the Royal Statistical Association, Series A, 129, 74-97.

Noga, T. J. \& Schnader, A. L. (2013). Book-Tax Differences as an Indicator of Financia Distress. Accounting Horizons, 27(3): $469-489$. 
INTERNATIONAL JOURNAL OF ACADEMIC RESEARCH IN BUSINESS AND SOCIAL SCIENCES

Vol. 8, No. 10, Oct. 2018, E-ISSN: 2222-6990 @ 2018 HRMARS

Noor, R. M., Mastuki, N., \& Aziz, Z. (2007). Earnings management and deferred tax. Malaysian Accounting Review, 6(1), 1-17.

Ohlson, J.A. (1995), Earnings, book values and dividends in equity valuation, Contemporary Accounting Research, 11 (2), 661-687. http://dx.doi.org/10.1111/j.19113846.1995.tb00461.x

O'Hara, T., Lazdowski, C., Moldovean, C. \& Samuelson, S. (2000). Financial Indicators of stock performance: West Haven. American Business Review.

Pathirawasam C., (2010). Value Relevance of Accounting Information: Evidence from Sri Lanka, International Journal of Research in Commerce and Management (IJRCM), Vol. 1(8), pp. 1320.

Phillips, J., Pincus, M., \& Rego, S. O. (2003). Earnings management: New evidence based on deferred tax expense. The Accounting Review, 78(2), 491-521.

Phillips, J., Pincus, M., Rego, S. O. \& Wan, H. (2004). Decomposing changes in deferred tax assets and liabilities to isolate earnings management activities. The Journal of the American Taxation Association, 26(Supplement), 43-66.

Petr, H. \& Hana, B.(2017). Comparison of deferred tax materiality reporting in accordance with continental and Anglo-Saxon reporting system. Acta Universitatis Agriculturae et Silviculturae Mendelianae Brunensis, 65(6): 1917 - 1924.

Ragab, A. A. \& Omiran M. M. (2006). Accounting information. value relevance, and Investors? Behaviour in the Egyptian equity market. Review of accounting and finance 5 (3) 20:279-297.

Schrand, C. M. \& Wong, F. (2003). Earnings management using the valuation allowance for deferred tax assets under SFAS No. 109, Contemporary Accounting Research 20 (3): 579-611.

Tharmila, K. \& Nimalathasan, B. (2013).The value relevance of accounting information and its impact on market vulnerability: a study of listed manufacturing companies in Sri Lanka. Merit Research Journal of Business and Management 1(2) pp. 030-036, December, 2013

Valix, C. \& Peralta, J. (2009). Financial accounting, Volume 2. Manila: GIC Enterprises \& Co.

Vijitha, P. \& Nimalathasan, B. (2014). Value relevance of accounting information and shareprice: A study of listed manufacturing companies in SriLanka" Merit Research Journal of Business and Management 2(1) pp. 001-006, January, 2014 Available online http://www.meritresearchjournals.org/fst/index.htm.

Weber, D. P. (2009). Do analysts and investors fully appreciate the implications of book-tax differences for future earnings? Contemporary Accounting Research 26 (4): 1175-1206. 
INTERNATIONAL JOURNAL OF ACADEMIC RESEARCH IN BUSINESS AND SOCIAL SCIENCES

Vol. 8, No. 10, Oct. 2018, E-ISSN: 2222-6990 @ 2018 HRMARS

Ying, W., Scott, B. \& Michael, C. (2016). Deferred tax items as earnings management indicators. CSMAR, the China Center for Economic Research. 